\title{
Opinber stefna, skólakerfið og hlutverk kennara: Viðbragđsbúnađur skólans
}

\author{
Sigrún Harđardóttir, lektor, Félagsráđgjafardeild, Háskóli Íslands \\ Sigrún Júlíusdóttir, prófessor, Félagsráđgjafardeild, Háskóli Íslands
}

\begin{abstract}
Útdráttur
Undanfarna áratugi hefur alpjóðleg umræða í velferðarsamfélögum beinst að vægi skólans sem undirstöðu velsældar einstaklings og samfélags. Hér er kannað hvernig pessi umræða hefur proskast við íslenskar aðstæður. Markmið greinarinnar afmarkast við að bregða upp mynd af áhrifum opinberrar skólastefnu á Íslandi á stöðu skólans, kennara og nemenda í nútímasamfélagi. Aðferðin sem hér er notuð er að setja fram sögulegt ágrip af próun skólamála og yfirlit um niðurstöður nýlegra íslenskra rannsókna um aðstæður og margvíslegar parfir nemenda og um viðbragðsbúnað skólans gagnvart peim. Í pví sambandi er vikið að vandasamri stöðu kennarans við að sinna kennslu og uppeldishlutverki jafnframt pví að láta sig varða velferð hvers barns, einkum innan grunnskólans. Einnig er athygli beint að rökum sérfræðinga fyrir pverfaglegu starfi innan skólans og kerfasamstarfi milli skóla, heilbrigðispjónustu og félagspjónustu. Rökin varða einkum börn sem eru tilfinningalega berskjölduð vegna áfalla eða félagslegrar jaðarstöðu. Á grundvelli peirrar vitneskju sem fengist hefur á pessu sviði er sú niðurstaða rökstudd að aukið fagafl innan skólans ásamt kerfasamstarfi kringum barn í vanda og fjölskyldu pess sé forsenda pess að draga úr álagi á kennara og koma í veg fyrir að kröftum peirra sé dreift. Aukinheldur hafi slíkt samstarf á grunnskólastigi forvarnargildi fyrir framtíðarstöðu ungs fólks á vinnumarkaði, sem getur falið í sér pjóðhagslegan ávinning. Ræddar eru lausnaleiðir í átt að betri árangri, meðal annars með endurskoðun laga, stjórnskipulags og framkvæmdar stefnu sem mótuð hefur verið.
\end{abstract}

Efnisorð: Skólastefna; skóli án aðgreiningar; hlutverk kennara; nemendur; fjölfaglegt kerfasamstarf. 


\title{
Public policy, the schoolsystem and teachers'role: Pathways of professional reforms for the benefit of pupils
}

\begin{abstract}
The article focuses on public school policy in Iceland, in a historical perspective, the teacher's role and contemporary challenges in the school system. Attention is paid to the increased complexity of teachers' role as educators and that of guarding the welfare and well-being of the individual schoolchild. The ongoing changes in teachers' role are related to changed social and family conditions coinciding with development in society and (human service) welfare institutions. This may especially regard school children when confronted by crises in their parents' lives or other unexpected, harmful situations in their personal life. Results from Icelandic research on current socio-educational conditions of schoolchildren and their families are presented. Increasing cooperation between school, health and social system with an interdisciplinary approach is advocated. Referring to present knowledge and call for revised legislation and policy issues some ideas of renewal of service are presented and discussed.
\end{abstract}

Keywords: School policy; teachers' role; inclusive school; school child; multidisciplinary support system.

\section{Inngangur}

Skólinn er fyrst og fremst menntastofnun og kjarnahlutverk kennara að styrkja námsproska og uppeldi skólabarnsins. Samhliða nýrri og breyttri skólastefnu um skóla án aðgreiningar hefur félagsmótunarhlutverk skóla aukist og víkkað (Gerður G. Óskarsdóttir 2012; Hermína Gunnpórsdóttir \& Dóra S. Bjarnason 2014). Páttur í pessu breytta og útvíkkaða hlutverki kennarans er að láta sig varða börn í erfiðum félagslegum aðstæðum og persónulegum vanda. Slík staða skólabarna endurspeglar meðal annars aðstæður íslenskra fjölskyldna í breyttu samfélagi, formgerð, efnahag, vinnumarkað, tæknileg og menningarleg atriði (Stefán Ólafsson \& Arnaldur Sölvi Kristjánsson 2017). Vandinn varðar margvíslega viðkvæma stöðu fjölda skólabarna, meðal annars vegna námserfiðleika og jaðarstöðu í félagahópnum, sem tengist fátækt og einelti, eða vegna áfalla í fjölskyldu, svo sem skilnaðar og andláts. Próunin hefur verið sú að nemendum í sérkennslu fjölgar og er áætlað að nú njóti allt að 25\% barna einhvers konar sérkennslu í grunnskóla (Samband íslenskra sveitarfélaga 2015). Vaxandi hlutfall greininga vegna félagsog tilfinningalegra örðugleika eða hegðunarvanda hefur áhrif á starf kennarans, líðan skólabarnsins og forsendur beggja til að njóta sín í skólastarfinu (Skóla- og frístundaráo Reykjavíkurborgar 2017). Fjölgun greininga, með miklum útlátum sveitarfélaga (Samband íslenskra sveitarfélaga 2017), án sampætts inngrips fagfólks getur leitt til eins konar greiningagildru sem barnið situr fast í.

Aukið álag í kennarastarfi tengist nýjum áskorunum vegna vaxandi fjölbreytileika í nemendahópnum, fjölgunar röskunargreininga, og nauðsynjar á sérpekkingu um málefni innflytjenda og flóttabarna. Fjallað hefur verið um pað hvernig staða kennarans hefur orðið flóknari og erfiðari en áður. Mörk kennarahlutverksins verða óljós og kröfur 


\section{STJÓRNSÝSLA}

um ábyrgð og lausnir geta orðið kennurum ofviða, enda liggja sum hinna nýju verkefna utan verksviðs peirra (Guðrún Kristinsdóttir 2011; Ingólfur Ásgeir Jóhannesson 2006a; Nanna Kristín Christiansen 2011). Kennarar hafa lengst af notið virðingar og öryggis í starfi en purfa nú að glíma við aukið álag og jafnvel vanmáttarkennd. Dví hefur verið haldið fram að álag og lág laun hafi gert kennarastarfið minna aðlaðandi og skert virðingu pess (Skóla- og frístundaráð Reykjavíkurborgar 2017). Starfsgleðin dvíni og sumir leiti í önnur störf. Samkvæmt tölulegum upplýsingum endurspeglast streita og álag í vaxandi eftirspurn eftir hvíld og starfsendurhæfingu (Pórunn Sveinbjarnardóttir 2018).

Mat kennara sjálfra er að peir hafi ekki fengið nægan undirbúning í námi til að mæta peim félagslega veruleika sem hér um ræðir. Deir búi ekki yfir faglegri pekkingu sem til parf, og ekki séu til staðar fagleg pjónusta og stuðningsfarvegir (Birna Sigurjónsdóttir 2017; Mennta- og menningarmálaráđuneytið 2017; Samband íslenskra sveitarfélaga \& Félag grunnskólakennara 2012). Pá hefur komið fram að menntun, skipulag og skýr verkaskipting kennara og skólastjórnenda skiptir miklu um árangur skólastarfsins (Trausti Dorsteinsson \& Amalía Björnsdóttir 2016). Brotthvarf úr framhaldsskólum er meira hér en í nágrannalöndunum og vísbendingar eru um að staða íslenskra grunnskóla sé óhagstæð miðað við nágrannalöndin (Norræna ráðherranefndin 2018). Petta kann að eiga sér margpæettar skýringar sem huga pyrfti betur að en eru ekki hér til umfjöllunar.

Í úttekt á framkvæmd stefnu um menntun án aðgreiningar á Íslandi (Mennta- og menningarmálaráðuneytið 2017) kemur fram að skýra purfi betur bæði hugtakið sjálft, „menntun án aðgreiningar“, og hvernig standa beri að framkvæmdinni. Núverandi löggjöf og stefnumótun feli í sér stuðning við markmið og áherslur skólakerfis án aðgreiningar en pörf sé á skýrari leiðsögn um pað hvernig fella á pessi stefnumið inn í áætlanir sveitarfélaga og skóla og hrinda peim í framkvæmd. Starfsfólk á öllum stigum skólakerfisins vinni af heilindum að framgangi stefnunnar en mjög skorti á að pað hafi notið nægilegs stuðnings. Í tillögum höfunda er lögð áhersla á að efla samstillt starf og virkja stuðningskerfi velferðarsamfélagsins á öllum skólastigum, draga úr (sjúkdóms) greiningum á vanda og forðast pannig greiningagildruna. Pannig megi laga námsumhverfið að menntun án aðgreiningar með heildstæðu framboði fjölfaglegrar pjónustu, bæði innan skólans og í kerfasamstarfi út á við, til stuðnings kennurum, nemendum og fjölskyldum. Dýpri umfjöllun um kenningarlegan grunn pessara hugmynda er ekki viðfangsefni pessarar greinar. Pó er vert að hafa í huga pá staðreynd að rekstur grunnskóla er hæsti einstaki kostnaðarliður sveitarfélaga (Samband íslenskra sveitarfélaga 2017).

Markmið pessarar greinar er að nýta vísbendingar frá athugunum innan stjórnsýslufræða og menntastefnufræða til að bregða upp mynd af áhrifum opinberrar skólastefnu á stöðu skólans, kennara og nemenda í íslensku nútímasamfélagi. Aðferðin sem hér er notuð er að fara yfir niðurstöður nýlegra íslenskra rannsókna um aðstæður og margvíslegar parfir nemenda og um viðbragðsbúnað skólans gagnvart peim og gefa um pær yfirlit. Vikið er að vandasamri stöðu kennarans við að sinna kennslu og uppeldishlutverki jafnframt pví að láta sig varða velferð hvers barns, einkum innan grunnskólans. Einnig er athygli beint að pekkingu og rökum sérfræðinga fyrir pverfaglegu starfi innan skólans og fjölfaglegu kerfasamstarfi milli skóla, heilbrigðispjónustu og félagspjónustu. 
Раð starf beinist einkum að börnum sem eru tilfinningalega berskjölduð vegna áfalla eða félagslegrar jaðarstöðu. Pessari aðferð hefur ekki verið beitt áður á pessu sviði og er nýmæli greinarinnar í pví fólgið. Fyrst er litið til sögulegrar próunar og síðan reynt að greina aðstæður nú út frá niðurstöðum valinna nýlegra íslenskra rannsókna.

Í samræmi við áðurgreind markmið er athygli sérstaklega beint að fyrirliggjandi pekkingu á pörfum grunnskólabarna sem hafa upplifað tilfinningalegt áfall, og að fjölfaglegu kerfasamstarfi, p.e. samstarfi skóla, heilbrigðispjónustu og félagspjónustu, um velferð pessara barna. Pótt sérpekking kennara snúi einkum að kennslu og uppeldisrækt er kennarinn miðlægur í slíkri teymisvinnu faghópa kringum skólabarnið.

\section{Sögulegt sjónarhorn}

Flokkun frávika hefur breyst í áranna rás og er pví á köflum erfitt að rekja skólasögu barna sem hafa purft sérpjónustu. Bent hefur verið á að einn helsti veikleikinn í pólitískri og faglegri umræðu um úrlausnir í málaflokknum sé sá að menn hneigjast til að líta á pann hóp barna sem parf sérstaka aðstoð sem einsleitan. Petta megi sjá af mismunandi hugtökum sem notuð hafa verið um pessi börn. Á árunum frá 1950 til 1970 var talað um afbrigðileg börn, frá 1970 til 2000 var talað um börn sem pyrftu sérkennslu af einhverju tagi en frá árinu 2000 hefur hugtakið börn með sérparfir verið notað (Jón Torfi Jónasson 2008). Sagan sýnir að nemendur hafa fengið sérfræðilega greiningu allt frá pví að almenningsskólar komust á laggirnar. Ástæðan var sú að hluti nemenda réð illa við pað sem skólinn ætlaðist til af peim (Gretar L. Marinósson \& Kristín P. Magnúsdóttir 2016). Skólagöngu barna með sérparfir var lengi vel sinnt á margvíslegum samfélagsstofnunum sem ekki voru beinlínis skólastofnanir (Jón Torfi Jónasson 2008).

Í kjölfar skyldunáms samkvæmt fyrstu almennu lögunum um barnafræðslu árið 1907 fóru erfiðleikar í námi, par á meðal slæleg skólasókn, að verða sýnilegri hjá sumum peirra barna sem áttu í félagslegum vanda. Kennarar lýstu pá áhyggjum af „,vandræðabörnum“ sem komin væru í skólana og skorti á úrræðum fyrir pau (Lög um fræðslu barna nr. 59/1907; Porsteinn Sigurðsson 1993). Um miðja 20. öld var komið á fót sérstökum heimilum og stofnunum til að annast uppeldi og menntun barna í vanda (Lög um vernd barna og ungmenna nr. 53/1966). Lagaákvæðin um vistun á heimilum óskyldra eða á stofnunum tóku til barna frá heimilum par sem talið var að uppeldið væri vanrækt og til barna sem póttu vera með slaka námsgreind, andlega vanproska eða höfðu ekki heilsu til að stunda venjulegt skólanám. Ýtarlega umfjöllun um úrræði fyrir skólabörn í vanda um og eftir miðja síðustu öld má finna í skýrslum Vistheimilanefndar sem kannaði starfsemi vist- og meðferðarheimila fyrir börn á peim tíma (Nefnd skv. lögum nr. 26/2007).

Með tilkomu sérkennslu í höndum sérmenntaðra kennara var viðurkennt að pörf væri á auknu fagafli og sérfræðipekkingu í skólum. Við setningu fyrstu heildstæðu grunnskólalaganna árið 1974 var öllum börnum 7 til 16 ára tryggð menntun. Skólinn skyldi stuðla að alhliða proska, heilbrigði og menntun hvers og eins, og kveðið skyldi með reglugerð á um sérkennslu fyrir börn með sérparfir. Í 67. grein er hlutverk sálfræðipjónustu skilgreint og áhersla lögð á að starfsmenn hennar veittu skólum ráð til að fyrirbyggja geðræn vandkvæði, önnuðust rannsóknir á peim sem ekki ná að nýta hæfileika sína í 


\section{STJÓRNSÝSLA}

námi og sæju um hæfniprófanir og ráðgjöf í sambandi við náms- og starfsval unglinga. Sinna skyldi nemendum sem sýna merki geðrænna erfiðleika og leiðbeina foreldrum og kennurum um meðferð peirra (Lög um grunnskóla nr. 63/1974).

Í kjölfar laganna 1974 var sett reglugerð um sérkennslu (nr. 270/1977) og önnur um ráðgjafar- og sérfræðipjónustu grunnskóla (nr. 21/1980). Samkvæmt henni skal fræðsluráð svo fljótt sem aðstæður leyfa setja á stofn slíka pjónustu fyrir grunnskóla. Að fengnum tillögum frá fræðslustjóra skal „ráða sálfræðinga, félagsráðgjafa og sérkennara“ til starfa (66. gr.). Ráðið var fagfólk samkvæmt pessu á sálfræðideildir skóla. Starfað var í náinni samvinnu við kennara og annað starfslið skóla um árabil. Starf félagstáðgjafanna fólst í að vinna á heildrænan hátt með nemendum, fjölskyldum peirra, kennurum og öðrum sem tengdust skólastarfinu að pví að greina sálfélagsleg vandamál einstakra nemenda og vinna að lausn peirra. Vegna skorts á félagsráðgjöfum voru aðrir smám saman ráđnir í störfin (Ella Kristín Karlsdóttir, Guðrún H. Sederholm, Sigrún Júlíusdóttir \& Valgerður Halldórsdóttir 2005). Námsráðgjöf var fyrst lögfest með grunnskólalögum nr. 49/1991. Við grunnskóla eða fræðsluskrifstofur skulu starfa námsráðgjafar sem annast náms- og starfsráðgjöf auk persónulegrar ráðgjafar. Við endurskoðun grunnskólalaga árið 1995 var rekstur grunnskóla fluttur til sveitarfélaga (Lög um grunnskóla nr. 66/1995). Par komu fram ný viðhorf, meðal annars um blöndun og heiltæka skólastefnu. bau eru byggð á peim félagslegu forsendum að orsakir erfiðleika hjá nemendum megi ekki síður rekja til umhverfispátta en einstaklingshindrana. Fræðimenn bentu á að leggja pyrfti áherslu á heildræna sýn á nemandann innan skólans og samræma vinnulag skóla og annarra opinberra stofnana sem koma að stuðningi við nemendur, meðal annars félagspjónustu og heilsugæslu. Pannig megi móta ný bjargráð, aðgerðir og lausnir með samstarfi á grundvelli kerfisnálgunar og hugsmíðahyggiu (Gretar L. Marinósson 1998; Guðríður Adda Ragnarsdóttir 1998; Sigrún Júlíusdóttir 1998). Með heildrænni sýn er hér átt við almenn og sértæk viðbrögð skólans og stofnanasamstarf út frá heildstæðri skólastefnu með aðstæður og sérparfir skólabarnsins í huga.

Markmið síðustu heildarlaga um grunnskóla (nr. 91/2008) er að stuðla í samvinnu við heimilin að alhliða proska allra nemenda og pátttöku peirra í lýðræðispjóðfélagi. Með lögunum er í fyrsta skipti skjalfest að grunnskólinn skuli vera án aðgreiningar með áherslu á lýðræði og félagslegt réttlæti í skólum. Đær áherslur má pó sjá í stefnu um sérkennslu hjá Reykjavíkurborg nokkru fyrr, eða frá árinu 2002 (Nefnd um sérkennslu og sérúrræði i Reykjavík 2002). Stefnan um skóla án aðgreiningar er eitt af áherslumálum Salamanca-yfirlýsingarinnar frá 1994 og vísar til ákveðinna gilda, vinnubragða og skipulags í skólastarfi á pá leið að skólar eigi að taka við öllum börnum hvernig sem á stendur um atgervi peirra til líkama og sálar og um félagslegt og tilfinningalegt ásigkomulag peirra (Menntamálaráðuneytið 1995). Í lögunum frá 2008 er kveðið á um að sveitarfélög skuli veita sérfræðipjónustu í skólum, annars vegar með stuðningi við nemendur og fjölskyldur peirra og hins vegar með stuðningi við starfsemi grunnskóla og starfsfólk peirra. Sveitarfélög sem reka grunnskóla skulu hafa frumkvæði að samstarfi milli sérfræðipjónustu, félagspjónustu, barnaverndaryfirvalda og heilbrigðispjónustu innan sveitarfélagsins vegna nemenda með sérparfir og langvinn veikindi. Prátt fyrir að íl lögunum séu félagsleg 
sjónarmið augljós hefur próunin orðið sú að samhliða innleiðingu stefnunnar um skóla án aðgreiningar hefur fjölgað mjög sálfélagslegum og læknisfræðilegum greiningum í sérfræðipjónustu grunnskóla og í sérkennslu (Hagstofa Íslands 2016). Fræðimenn hafa bent á að sjúkdómstengd greiningarheiti séu notuð í auknum mæli um allar tegundir líkamlegs og andlegs ástands og hegðunar. Мeð pví að styðjast við slíkar greiningar í skólastarfi sé ýmiss konar hegðun gerð að læknisfræðilegu viðfangsefni. Gjalda verði varhug við pví að ofgreina eða sjúkdómsgera vanlíðunar- og hegðunareinkenni sem eiga sér rætur í fjölskyldu- eða samfélagsaðstæðum (Sigrún Júlíusdóttir 2001; Tomlinson 2012). Раð verði að varast sjúkdómsgervingu alls vanda sem vart verður í skólastarfi, bæði vegna nemandans sem á að aðstoða og vegna pess að slíkar greiningar geti beinlínis unnið gegn stefnunni um skóla án aðgreiningar (Gretar L. Marinósson \& Kristín P. Magnúsdóttir 2016; Hermína Gunnpórsdóttir \& Dóra S. Bjarnason 2014; Ingólfur Ásgeir Jóhannesson 2006b).

Pessi próun í grunnskólalöggjöfinni hefur einkennst af áherslu á að bæta námsgetu og jafna stöðu nemenda með námshindranir. Hvort tveggja skyldi stuðla að pví að draga úr brotthvarfi nemenda í pessum hópum. Við lagabreytingarnar hefur pó verið horft framhjá dýpri forsendum pess að ná slíku markmiði, p.e. að stefnan taki mið af greiningu innri og ytri aðstæðna í heildarsamhengi. Á nýlegri ráðstefnu á vegum velferðarráðuneytisins (2018) um snemmtæka íhlutun í málefnum barna birtist petta sama sjónarhorn með áherslu á traust milli faghópa og samstarf milli kerfa.

\section{Aðferð}

Sú aðferð sem notuð var til að ná áðurnefndu markmiði greinarinnar um skólastefnu, hlutverk kennara og aðstæður nemenda á skólaskyldualdri, 6-18 ára, fólst í pví að greina próun og stöðu út frá nýlegum íslenskum rannsóknum og fagumræðu um pær. Leitast var við að afmarka yfirlitið við birt vísindalegt efni sem snertir fræðasvið og stöðu skólamála. Meginspurningin sem leitað var svara við var: Mætir umgjörð skólaumhverfisins pörfum nemenda og foreldra og breyttu hlutverki kennara í nútímasamfélagi?

Til að afmarka efniviðinn sem lagður skyldi til grundvallar voru rannsóknirnar valdar út frá ákveðnum áhersluatriðum: (1) útvíkkað hlutverk kennara, (2) sálfélagslegur vandi nemenda og viðbragðsbúnaður skólans, (3) áfallaáætlanir og áfallahjálp í skólum, (4) viðbrögð skólans pegar nemandi á um sárt að binda vegna veikinda eða andláts í fjölskyldu, (5) afdrif nemenda sem hverfa frá námi.

Rannsóknirnar sjálfar voru jafnframt valdar út frá peim viðmiðum að pær (i) væru unnar á síðustu tveimur áratugum, (ii) væru sjálfstætt framlag fræðimanna á viðkomandi sviði, (iii) fjölluðu um opinbera pjónustu samkvæmt lögum og reglum í págu nemenda og skólaumhverfisins, (iv) gæfu vísbendingar um parfir nemenda og viðbrögð skólans við peim, (v) greindu stöðu og afdrif ungmenna sem hrakist hafa frá námi.

\section{Staða pekkingar um viðbrögð skólans við vanda skólabarna}

Fræðimenn í vestrænum pjóðfélögum hafa fjallað um stuðning skóla við barn sem verður fyrir sálfélagslegu áfalli í fjölskyldu sinni, veikindum og ástvinamissi, eða fær á 
sig sjúkdómsstimpil af ýmsum ástæðum og missir fótanna. Rökstutt er að viðbragðsáætlun innan skóla geti skipt sköpum um líðan barnsins og framtíðarvelferð (Dyregrov 1993; Gunnar E. Finnbogason 1998; Allen \& Ashbaker 2004; Hjern, Berg, Rostila \& Vinnerljung 2013). Fræðimönnum og fagfólki ber saman um að viðbragðsáætlanir geti skilað árangri með aðkomu viðeigandi fagstyrks innan skóla og skipulegu samstarfi pjónustukerfa sem koma að heilsu og velferð barna, p.e. heilbrigðis-, félags- og skólakerfis og jafnvel réttar- og fangelsiskerfis (Guðrún Kristinsdóttir 2011; Sigrún Júlíusdóttir 2005; 2012). Hér purfi að stilla saman strengi í pverfræðilegri nálgun byggðri á pví viðhorfi að skólinn láti sig varða tilvist barnsins í heild. Pannig sé grunnpjónusta heilsugæslu og félagspjónusta sveitarfélaga samtengd skólastarfi með skólabarnið og fjölskyldu pess í brennidepli. Slíku starfi til stuðnings purfi leiðbeinandi lagaákvæði um skyldu skólans við pessar aðstæður, og um pað hvernig skuli útfæra stofnanasamstarf, fræðslu, stuðning og beinar forvarnir. Síðustu áratugi hafa birst ritsmíðar á íslenskum vettvangi par sem pessar breyttu áherslur eru rökstuddar (Gretar Marinósson 1998; Guðríður Adda Ragnarsdóttir 1998; Menntamálaráðuneytið 1999; Sigrún Júlíusdóttir 1998) með vísun til innleiðingar nýrrar menntastefnu.

Hér fer á eftir yfirlit um pekkingu um íslenskar aðstæður að pessu leyti. Vísbendingar um stöðuna og hvar skórinn kreppir eru nokkuð samhljóða. Ályktanir sem af peim eru dregnar ber einnig að sama brunni og verða pær ræddar í umræðukafla í lok greinar.

\subsection{Rannsóknir um útvíkkað̃ hlutverk kennara}

Með hugtakinu útvíkkað hlutverk kennarans er átt við pær breytingar á hlutverki kennara sem orðið hafa og fela í sér ákveðin afskipti af aðstæðum nemenda auk kennslu og uppeldis. Með pessu víkkar umgjörð hlutverksins par sem kennarinn hefur sjálfur gát á heildarliððan nemenda með liðsinni annarra faghópa innan skóla og samstarfi peirra við pjónustukerfi utan skólans.

Rannsóknir hafa sýnt að mikið álag er á kennurum og stjórnendum grunnskóla og að hegðunarerfiðleikar nemenda valda starfsmönnum hvað mestum áhyggjum (Guðbjörg Ólafsdóttir \& Berglind Rós Magnúsdóttir 2017; Ingvar Sigurgeirsson \& Ingibjörg Kaldalóns 2006). Í skýrslu starfshóps um sérfræðipjónustu skóla (Menntasvið Reykjavíkurborgar 2008) kemur fram að megináherslan í sérfræðipjónustu skóla hafi verið lögð á læknisfræðilega nálgun par sem læknar og aðrir sérfræðingar „lækni“ nemendur sem eiga við geðrænan, tilfinningalegan eða félagslegan vanda að stríða. Í niðurstöðum kemur fram að auka purfi fjölbreytni í sérfræðipjónustu til að sinna sértækum pörfum nemenda og færa sérfræðinga í ríkari mæli inn í skólann, á vettvang kennara og nemenda.

Í könnun meðal íslenskra grunnskólakennara á vegum Sambands íslenskra sveitarfélaga og Félags grunnskólakennara (2012) sögðu prír kennarar af hverjum fjórum að álag í starfi hefði aukist mikið. Aðspurðir hvað væri erfiðast í starfinu nefndu kennarar einkum pessi atriði: a) samstarf við foreldra pegar barn fær ekki næga aðstoð heima vegna ófullnægjandi heimilisaðstæðna, b) erfiðir nemendur (ódælir og með sérparfir) og agavandamál, c) flókin eineltismál sem torvelt er að uppræta, d) barnaverndarmál par sem pungbært er að horfa upp á vanrækt börn. Jafnframt sögðust peir ekki hafa 
fengið nægan undirbúning í kennaranáminu til að sinna hegðunarvandamálum, eineltismálum, sérpörfum og sjúkdómum ásamt almennu foreldrasamstarfi. Prír kennarar af hverjum tíu töldu ganga illa eða mjög illa að vinna eftir hugmyndafræðinni um skóla án aðgreiningar.

Í nýlegri rannsókn (Sigrún Harðardóttir \& Ingibjörg Karlsdóttir, bíður birtingar) um reynslu kennara af pví að sinna nemendum með námserfiðleika kemur fram að álag á kennara fer vaxandi. Viðmælendur voru sammála um að skólarnir búi yfir góðu og vel menntuðu starfsfólki sem sé tilbúið að leggja sig fram. Aukið og illviðráðanlegt álag fylgi pví hins vegar að sinna velferð hvers barns í skóla án aðgreiningar. Mesta áskorunin sé að takast á við fjölbreytileikann í nemendahópnum og mæta pörfum hvers og eins. Par ber hæst að fást við margvíslegan náms- og hegðunarvanda nemenda og sinna pörfum barna af erlendum uppruna. Viðmælendur segja að pótt nemendur glími við svipaðan vanda séu einstaklingsparfir og forsendur misjafnar. Hlutverk kennara felist í að finna hvað hentar hverjum og einum best. Niðurstöðurnar sýna að kennurum er pað mikil áraun að horfa upp á börn sem glíma við vanlíðan, áföll í fjölskyldum, fátækt og félagslega útskúfun, og að peir upplifa sig hjálparvana í pessum aðstæðum. Að mati kennara skortir aðstoð fagfólks í slíkum málum, félagsráðgjafa og annarra sérfræðinga.

Í rannsókn Snæfríðar Drafnar Björgvinsdóttur og Önnu Lindar Pétursdóttur (2014) var leitast við að kanna umfang erfiðrar hegðunar í skólastofunni. Pátttakendur voru 95 umsjónarkennarar og sérkennarar úr níu grunnskólum í Reykjavík. Niðurstöðurnar sýna að kennarar telja að um fjórðungur nemenda sýni erfiða hegðun og að margir kennarar purfa að fást við hegðunarvanda daglega. Einnig var kannað hvaða áhrif erfið hegðun nemenda hefur á kennara og hvar peir geta leitað stuðnings. Allt að priðjungur kennara fann fyrir einkennum tilfinningaprots og rúmlega helmingur íhugaði að hætta kennslu vegna álags af erfiðri hegðun nemenda. Jafnframt kom fram að kennarar fengju oftast stuðning frá samstarfsfólki, en meirihluti sagðist sjaldan eða aldrei fá aðstoð sérfræðings til að takast á við erfiðleikana.

Niðurstöður rannsóknar sem fram fór árið 2017 á vegum Skóla- og frístundaráðs Reykjavíkurborgar, og kennarar úr öllum skólum borgarinnar tóku pátt í (Birna Sigurjónsdóttir 2017) sýna að pær miklu breytingar sem hafa orðið á (útvíkkuðu) starfi kennarans á undanförnum árum stafa meðal annars af innleiðingu stefnu um skóla án aðgreiningar. Stefnan sem slík sé pó ekki álagspáttur í sjálfu sér heldur bað að enn vantar pær bjargir sem slík stefna kallar eftir. Pátttakendur ítrekuðu að peir væru undir miklu álagi vegna erfiðra samskipta við foreldra, agamála og hegðunartruflana nemenda, ásamt félagslegum vandamálum í fjölskyldum peirra. Stuðning skorti sárlega fyrir kennara í slíkum málum. Peir óskuðu eftir fleiri fagmenntuðum sérfræðingum inn í skólana og betra aðgengi að stoðpjónustu, sem nú sé lítil sem engin. Раð purfi að bíða lengi eftir greiningum og skortur sé á viðeigandi viðbrögðum, ekki síst á úrræðum í kjölfar greiningar. Starfshópur á vegum Skóla- og frístundaráðs Reykjavíkurborgar (2017) lagði fram tillögur um aðgerðir út frá pessum niðurstöðum í peim tilgangi að bæta vinnuumhverfi innan grunnskóla. Par er lagt til að að fjölgað verði fagfólki sem starfar við hlið kennara í grunnskólum. Er par átt við félagsráðgjafa og náms- og starfsráðgjafa ásamt hegðunar- 


\section{STJÓRNSÝSLA}

ráðgjöfum, sálfræðingum, talmeinafræðingum og proskapjálfum. Starfshópurinn lagði einnig til að mótuð yrðu ný úrræði vegna barna í fjölpættum vanda og stæðu pau skólunum til boða frá og með skólaárinu 2018-2019. Með peim ætti meðal annars að mæta pörfum barna með alvarlegan hegðunarvanda og geðraskanir. Jafnframt var lagt til að efla handleiðslu og ráðgjöf til kennara.

Í skýrslu sem unnin var fyrir mennta- og menningarmálaráðuneytið (2015a) um framkvæmd stefnu um skóla án aðgreiningar kemur fram að erfitt sé að framfylgja stefnunni pótt litið sé jákvæðum augum á hugmyndafræðina að baki. Að mati skýrsluhöfunda er mikilvægt að skýra hvað stefnan pýðir í raun og hvað purfi til að framkvæma hana. Hún hafi hvorki verið skilgreind né innleidd með nægilega skipulegum hætti. Enn er lögð áhersla á að efla purfi rannsóknarstarf, endurskoða starfshætti og stuðning við kennara og tryggja samræmd vinnubrögð í sérfræðipjónustu skóla, skýra verksvið og samstarf aðila og auðvelda aðgengi að sérhæfðum úrræðum. Að mati starfshópsins virðast stjórnvöld ekki hafa skilgreint fyrirfram hvað pessi sampætta heildstæða pjónusta við nemendur samkvæmt lögunum frá 2008 pýddi í raun. Auk pess hafi verklag og skipulag skólastarfs og laga- og reglugerðarumhverfi einstakra kerfa ekki verið nægilega samhæft. Pví sé ýmislegt gagnrýnivert í framkvæmd liðinna ára. Mikilvægt sé að sveitarfélög og ríki hugi að „gráu svæðunum“ í verkaskiptingu sinni á sviði velferðarpjónustunnar. Sökum pess að meinbugir hafi verið á undirbúningi og framkvæmd skólastefnunnar sé erfitt að leggja mat á hvernig til hefur tekist.

Af framangreindum rannsóknum má sjá að mikið álag er á kennurum. Í pví sambandi er vert að árétta að fjöldi kennara, og pá einkum kvenna, sem greinast með starfspreytu eða jafnvel starfsprot, hefur aukist vegna nýrra álagspátta í starfi, sbr. útvíkkað starfshlutverk, og skorts á handleiðslu. Í gögnum VIRK starfsendurhæfingarsjóðs sést að 18\% peirra sem pangað leita eru háskólamenntaðir og að kennarar leita áberandi meira í starfsendurhæfingu en aðrar háskólamenntaðar stéttir. Par kemur fram að kennarar séu hópur sem glímir oftar við kvíða, andlegt álag og vefjagigt en aðrir háskólamenntaðir starfsmenn. Vigdís Jónsdóttir telur í grein um VIRK og starfsendurhæfingu að petta séu vísbendingar um að talsverðum hópi bæði nemenda og kennara líði ekki nógu vel innan skólakerfisins. Erfitt sé að segja til um hvort orsakirnar liggja par, annars staðar í samfélaginu eða í flóknu samspili milli skólakerfis, fjölskyldu, breyttra uppeldisaðferða og annarra stofnana samfélagsins. Full ástæða sé til að skoða petta frekar og leita lausna (Vigdís Jónsdóttir 2017; Vigdís Jónsdóttir, munnleg heimild 16. maí 2018). pórunn Sveinbjarnardóttir, stjórnarformaður Virk (2018), hefur vakið athygli á pví að tveir priðju hlutar peirra sem leita til Virk séu konur og að mikil fjölgun hafi par orðið í hópi háskólamenntaðra kvenna á liðnum árum. Petta gefi vísbendingar um að álag á konur á vinnumarkaði sé óhóflegt og skapi hættu á streitu og einkennum tilfinningaprots. Í tengslum við petta vísar Pórunn í rannsóknir sem sýna að vinnuskilyrði eru oftar slæm á vinnustöðum par sem konur eru í meirihluta en á „karlavinnustöðum“, svo sem í menntakerfinu par sem kennarar standa oft frammi fyrir óljósum eða óraunhæfum kröfum (Corin \& Björk 2016; Ingibjörg H. Jónsdóttir 2017; Snæfríður Dröfn Björgvinsdóttir \& Anna Lind Pétursdóttir 2014). Í framhaldi af peim niðurstöðum rannsókna um 
útvíkkað hlutverk kennara sem lýst hefur verið hér að ofan verður athyglinni nú beint að stöðu nemenda.

\subsection{Vandi nemenda og viðbragðsbúnaður skólans}

Árið 1997 skipaði páverandi menntamálaráðherra nefnd um eflingu náms- og starfsráðgjafar á öllum skólastigum. Nefndin gerði úttekt um mál sem bárust námsráðgjöfum á landsvísu, og flokkaði pau eftir tegundum og úrræðum. Fram kom að persónuleg ráðgjöf veldur verulegu álagi á námsráðgjafa, pá sérstaklega hin flóknu tilvik sem spretta af samskiptaerfiðleikum á heimilum, geðrænum sjúkdómum og félagslegum vanda og einkennast meðal annars af fátækt, vímuefnanotkun, pungun, nauðgun, sifjaspellum og ofbeldi. Flestir nefndu að erfitt væri að vísa málum áfram til frekari úrlausnar. Fram kom hjá svarendum ákall um hjálp við hin pyngri persónulegu mál sem peir sögðu sig skorta faglegan undirbúning til að sinna. Niðurstaða nefndarinnar var sú að ætti pjónusta við nemendur að skila árangri væri nauðsynlegt að par til bærir sérfræðingar kæmu að verki pegar um væri að ræða persónuleg mál, erfiðar fjölskylduaðstæður og flókna félagslega erfiðleika (Menntamálaráðuneytið 1998).

Rannsókn Fræðslumiðstöðvar Reykjavíkur frá árinu 2000 sýndi að ákvörðun um að veita nemendum grunnskóla sérkennslu var stundum tilviljunarkennd, p.e. ekki var byggt á námsframmistöðu nemenda í námsgreinum. Til dæmis var sumum nemendum með háa einkunn í íslensku beint í sérkennslu í lestri. Pegar skýringa var leitað kom fram að sumum nemendum sem trufluðu skólastarfið hafði verið vísað í sérkennslu í lestri til að losna við pá úr bekknum, óháð getu peirra í lestri, en ekki brugðist við sjálfum hegðunarvandanum og hindrunum sem af honum hljótast á næsta skólastigi (Ragnar F. Ólafsson \& Kristín Jónsdóttir 2006).

Rannsóknir hafa sýnt að ein helsta skýringin á brotthvarfi úr framhaldsskóla er slök námsstaða við upphaf náms í framhaldsskóla (Gerður G. Óskarsdóttir 1995; Jón Torfi Jónasson \& Guðbjörg Andrea Jónsdóttir 1992; Sigrún Harðardóttir 2015b). Aðrar skýringar hafa komið fram og snúa meðal annars að skuldbindingu nemenda til náms (Kristjana Stella Blöndal \& Atli Hafpórsson 2018). Í nýlegri rannsókn kannaði Sigrún Harðardóttir (2015a) tengsl sálfélagslegrar líðanar nemenda við upphaf náms í framhaldsskóla við námsframvindu. Rannsóknin náði til priggja árganga nemenda sem byrjuðu í framhaldsskóla haustin 2005-2007, alls 270 nemenda. Niðurstöður mælinga á líðan sýndu að nemendur með námsvanda bjuggu við slakari sálfélagslega líðan við upphaf náms í framhaldsskóla en aðrir nemendur á bóknámsbrautum. Af nemendum sem hófu nám á hefðbundnum bóknámsbrautum til stúdentsprófs höfðu 9\% fengið greiningu á námsvanda í grunnskóla en 60\% nemenda sem hófu nám á pánefndri almennri braut. Meirihluti peirra sem hófu nám á bóknámsbrautum hafði lokið námi að fjórum og hálfu ári liðnu, eða $72 \%$, en einungis 16\% peirra nemenda sem áttu við námsvanda að stríða og hófu nám á almennri braut.

Árið 2017 sendi Velferðarvaktin frá sér tillögur um aðgerðir til að auka hlutfall nemenda sem ljúka framhaldsskólanámi (Velferðarvaktin 2017). Í inngangi segir að nefndin telji mikilvægt að sem flestir stundi nám við hæfi. Með pví sé stuðlað að farsælu lífi ungs 


\section{STJÓRNSÝSLA}

fólks til framtíðar og sé mikið brotthvarf nemenda úr framhaldsskólum á Íslandi pví áhyggjuefni. Nefndin leggur meðal annars til að forvarnir verði styrktar og brugðist strax við með heildrænum hætti pegar upp kemur vandi hjá nemendum. Fjölga purfi fagfólki innan skóla og efla pannig aðgengi að pjónustu félagsráðgjafa, náms- og starfsráðgjafa og annarra sérfræðinga.

Af peim rannsóknarniðurstöðum sem hér hafa verið raktar er ljóst að sérkennsluúrræði og náms- og starfsráðgjöf eru talin nauðsynleg og árangursrík. Enn hafi skólinn pó ekki bolmagn til að sinna sérhæfðri pjónustu fyrir börn sem stríða við alvarlega erfiðleika og viðvarandi sálfélagslegan vanda. Petta á sömuleiðis við um börn sem verða fyrir fjölskylduáföllum sem tengjast veikindum, slysum, andláti og skilnaði foreldra. Nú verður vikið að peim.

\subsection{Rannsóknir um áfallaáætlun og áfallahjálp í skólum}

Nokkrar rannsóknir á áfallaáxtlunum skóla hafa verið gerðar hér á landi. Rannsókn Gunnars E. Finnbogasonar og Hildar Bjargar Gunnarsdóttur (2010) hafði pað að markmiði að afla upplýsinga um pá grunnskóla á Íslandi sem samið hafa áfalla- eða viðbragðsáætlanir. Skoðað var inntak áfallaáætlunar í hverjum skóla og pær bornar saman. Áfallaáætlun er par skilgreind sem „,viðbragðsáætlun sem grunnskólar hafa samið til að geta á sem fagmannlegastan hátt brugðist við skyndilegum áföllum hjá nemendum“. Niðurstöður sýna að af 172 grunnskólum landsins petta ár höfðu 97, eða 56\%, áfallaáætlun, og var getið áfallateymis í 85\% af peim skólum. Áherslan í pessum áætlunum var hins vegar lögð á mismunandi pætti og pær voru misýtarlegar, meðal annars vegna breytilegra aðstæðna og ólíkrar reynslu af pví að vinna með áföll í skólastarfi. Fram kemur að skólastjóri ber jafnan ábyrgð á frumkvæði og aðgerðum ásamt föstu starfsliði, svo sem ritara og deildarstjóra. Aðkoma hefðbundinna fagstétta annarra en kennara í áfallateymum er mest af hálfu (skóla)hjúkrunarfræðinga og námsráðgjafa. Samstarf stofnana velferðarkerfisins var talið mikilvægt í allri áfallavinnu. Í 86\% áætlananna beinist athygli einkum að fyrstu viðbrögðum við áfalli og verklagi sem skyldi viðhaft. Í 63\% peirra var nefnt að einhvers konar eftirfylgni við barn skyldi fara fram í skólanum eftir áfall. Rannsakendur telja nauðsynlegt að endurskipuleggja áfallaáætlanir eftir pörfum og aðstæðum, og tryggja upplýsingaflæði milli aðila, p.e. láta alla sem tengjast skólastarfinu vita pegar skólabarn verður fyrir áfalli. Huga purfi að sérstöðu nemenda sem eiga bakgrunn í annarri menningu og trúarbrögðum en algengast er, tryggja pekkingu á pví sviði og hafa samstarf við fjölskyldur barnanna. Ályktað er um nauðsyn leiðbeininga, verkferla og samstarfs sérfræðinga í pverfaglegu áfallateymi fagfólks með reynslu og sérfræðipekkingu um sorg og áfallavinnu.

Í meistararannsókn um áfallaáætlun og áfallahjálp í skólum voru könnuð viðbrögð leik- og grunnskóla við andláti í fjölskyldu skólabarns (Elfa María Geirsdóttir 2016). Upplýsingar fengust með símtölum við skólastjórnendur og stöðluðum spurningalista frá stjórnendum 29 leikskóla og 21 grunnskóla. Leitast var við að fá heildstæða mynd af viðbrögðum skólanna, og af pví hvernig staðið er að áætlanagerð, úrræðum og framkvæmd, og var einnig leitað álits skólastjórnenda um úrbætur. Prír af hverjum fjórum 
skólum reyndust hafa skriflega áfallaáætlun. Fleiri grunnskólar en leikskólar höfðu slíka áætlun, og fleiri skólar á höfuðborgarsvæðinu en á landsbyggðinni. Í áfallaáætlun skólanna reyndist megináhersla lögð á fyrstu viðbrögð við áfalli. Í rúmum priðjungi tilfella var gert ráð fyrir langtímastuðningi við barn. Meirihluti skólastjórnenda taldi hins vegar pörf á áætlun um slíkan stuðning í öllum skólum. Um fjórðungur skóla er ekki með skriflega áfallaáætlun og ályktaði rannsakandi að tryggja pyrfti með lögum að skólar hefðu skriflega áfallaáætlun og gerðu ráð fyrir langtímastuðningi fyrir skólabörn vegna andláts foreldris. Sömuleiðis pyrfti að vera ljóst hvaða fagaðilar skuli veita barni aðstoð og hvernig skuli tryggja hana, bæði fyrir viðkomandi barn og starfsfólk skólans. Rannsakandi ályktar að lögbinda purfi aðkomu sérfræðinga innan skólans og sömuleiðis kerfasamstarf með pverfræðilegri nálgun, og vísar til erlendra fyrirmynda í pví efni (Franklin, Harris \& Montgomery 2015). Pá eru færð rök að pví að félagsráðgjafar, sem eru sérhæfðir til að takast á við málefni nemenda út frá félagslegum og tilfinningalegum pörfum barnsins og fjölskyldu pess, leggi sitt af mörkum í áfallateymum skóla og við uppbyggingu heildræns skipulegs samstarfs við önnur pjónustukerfi. Hér reyni oft á pekkingu á löggjöf sem varðar sjálfstæðan rétt barnsins í sáttavinnu kringum skilnað og pegar togstreita er í fjölskyldu pess um forsjá og búsetu eftir andlát foreldris (Sigrún Júlíusdóttir \& Sólveig Sigurðardóttir 2013).

\subsection{Rannsóknir um stöđu skólabarns við áfall í fjölskyldunni}

Á árunum 2015 til 2018 fór fram rannsókn á aðstæðum barna og fjölskyldna pegar foreldri hefur greinst með krabbamein. Fyrir henni stóð Rannsóknastofnun í barna- og fjölskylduvernd í samstarfi við Landspítalann og Ráðgjafarpjónustu Krabbameinsfélagsins. Athygli var meðal annars beint að viðbrögðum grunn- og framhaldsskóla við peim aðstæðum. Pessi hluti rannsóknarinnar byggðist bæði á upplýsingum frá fagfólki í heilbrigðis-, félags- og skólakerfi og frá fjölskyldunum sem komu við sögu en beindist einnig að löggjöf um hlutverk skólans.

Fyrsti hluti rannsóknarinnar fólst í pverfræðilegri rýnihópasamræðu starfsfólks á krabbameinsdeildum Landspítalans (Sigrún Júlíusdóttir, Gunnjóna Una Guðmundsdóttir \& Edda Jóhannsdóttir 2015). Meginniðurstöður voru að skortur væri á pekkingu og viðeigandi löggjöf um stuðning við börn. Í öðrum hluta var aflað gagna með persónulegum viðtölum, alls 31, við eftirlifandi nána aðstandendur látinnar móður, maka hennar eða barnsföður, börn hennar og móður (ömmu barnanna), i 15 fjölskyldum (Sigrún Júlíusdóttir \& Gunnjóna Una Guðmundsdóttir 2017). Fram kom hjá öllum viðmælendum, börnum, feðrum barnanna og ömmum, að almennt hafi pað verið foreldrar barnanna eða ömmur sem höfðu samband við skólann og greindu frá veikindum móður barnsins, stundum án pess að börnin vissu af pví. Oft hafi pá verið undir hælinn lagt hvort barnið mætti skilningi eða fékk viðeigandi hjálp. Viðmælendur lögðu áherslu á að kennarar slíkra barna fái upplýsingar um veikindaferlið til að geta veitt barninu sem bestan stuðning, meðal annars leiðsögn um pað sem snýr að félögum, skólagöngunni og sjálfu náminu.

Í heild lýstu börnin sjálf, feður peirra og ömmur takmörkuðum og tilviljunarkennd- 
um afskiptum skólans gagnvart líðan og aðstæðum skólabarns sem verður fyrir áfalli pegar lífsógnandi sjúkdómur greinist hjá móður og dregur hana síðan til dauða. Var pví lýst hvernig skortur á verkferlum og farvegum til samstarfs hafði hindrað upplýsingaflæði og átt sinn pátt í að samskipti við skólann urðu ómarkviss og fálmkennd. Ályktað er að pessi reynsla staðfesti að grunn- og framhaldsskólar purfa að hafa vegvísa til að vinna eftir. Skilningur og viðbrögð skólastjóra og umsjónarkennara virðist skipta mestu máli, meðal annars til að hjálpa barninu að bregðast við truflun á einbeitingu og aðstoða pað við að halda sínu striki. Svo virtist sem almennt hafi náðst meira og betra samband við grunnskóla barnanna en framhaldsskóla við veikindi og andlát foreldris.

Lokahluti rannsóknarinnar fólst í sex mánaða tilraunaverkefni með gæðapjónustu á Landspítalanum fyrir fjölskyldur par sem foreldri hefur greinst með krabbamein (Sigrún Júlíusdóttir, Gunnjóna Una Guðmundsdóttir \& Sigurlína Davíðsdóttir 2018). Pótt ekki væri unnið með skólum í verkefninu kom fram hjá pátttakendum að peir óskuðu meiri og betri samskipta við skólann vegna viðkvæmrar stöðu barnanna. Einfalda pyrfti upplýsingaflæði, meðal annars með upplýsingabæklingi og leiðbeiningum um samskiptaleiðir milli heilbrigðisfagfólks, fjölskyldunnar og skólans.

\subsection{Rannsóknir um afdrif nemenda sem falla úr skóla}

Hópur nemenda sem hverfa frá skólanámi hefur verið skilgreindur sem „peir einstaklingar sem ekki hafa farið í nám að loknum grunnskóla eða hafa hætt í framhaldsskóla“ (Jón Torfi Jónasson \& Kristjana Stella Blöndal 2002). Brotthvarf snertir bæði einstakling og samfélag og rýrir lífsgæði peirra sem fyrir pví verða. Аð auki kann samfélagið að verða fyrir meiri útgjöldum peirra vegna en annarra nemenda við bótagreiðslur, í félags- og heilbrigðispjónustu og síðar í starfsendurhæfingu (Björk Vilhelmsdóttir 2018; Gestur Guðmundsson 2002). Í greiningu á hagrænum áhrifum brotthvarfs kemur fram að pjóðfélagslegan kostnað af brotthvarfi hvers nemanda úr námi megi meta 14 milljónir á verðlagi ársins 2012. Er pá litið til pjóðfélagsins í heild til langs tíma, par sem brotthvarf hefur áhrif á alla framtíð viðkomandi einstaklinga (Eiríkur Sigurðsson 2014).

Ungmenni sem ekki ljúka námi standa verr að vígi á vinnumarkaði en önnur og hætta er á að pau verði útundan í samfélagi sem byggist á tæknipekkingu, tungumálakunnáttu og pjálfuðum vinnubrögðum við að setja sig inn í ný og framandi verkefni (Stefán Ólafsson \& Jóhanna Rósa Arnardóttir 2008). Rannsókn sem byggð var á markaðskönnun Hagstofu Íslands bendir til að menntun gefi sterka vísbendingu um hvers konar störfum ungmenni eiga kost á, umfram pað sem formlegar kröfur segja til um (Jóhanna Rósa Arnardóttir 2015). Upplýsingar frá Vinnumálastofnun (2019) sýna að atvinnulausum ungmennum hefur fjölgað. Í apríl 2019 voru 860 einstaklingar á aldrinum 18-24 ára á atvinnuleysisskrá sem samsvarar um 2,8\% skráðu atvinnuleysi. Atvinnulausum ungmennum hefur fjölgað um 293 frá apríl 2018 pegar fjöldi atvinnulausra á pessu aldursbili var 567. Ungt fólk sem er hvorki í vinnu, námi né annarri skipulegri pjálfun getur átt á hættu að verða félagslega einangrað, hafa tekjur undir fátækramörkum og geta ekki bætt fjárhagsstöðu sína (OECD 2018.)

Félagsvísindastofnun Háskóla Íslands (2016) vann rannsókn fyrir velferðarráðuneyt- 
ið til að varpa ljósi á stöðu ungmenna með endurhæfingar- og örorkulífeyri. Áhersla var lögð á að kanna reynslu af stuðningi sem ungmennin höfðu fengið og afla ábendinga um pað sem betur mætti fara. Niðurstöður sýndu að vandi pessa unga fólks birtist á margvíslegan hátt snemma á lífsleiðinni. Degar frá eru skildir meðfæddir sjúkdómar pjáðust 28\% ungs fólks á örorku- eða endurhæfingarlífeyri af sjúkdómum tengdum stoðkerfi og 72\% af geðsjúkdómum. Pá kom fram að ríflega helmingur pátttakenda hafði orðið fyrir einelti í grunnskóla. Um 75\% hópsins höfðu fundið fyrir kvíða eða punglyndi strax í grunnskóla og 58\% höfðu litla trú á sjálfum sér. Niðurstöðurnar voru svipaðar um reynslu fólksins af framhaldsskóla. Helmingur hópsins var mjög eða frekar sammála peirri fullyrðingu að hafa fengið lítinn eða engan stuðning í grunnskóla, og rúmlega priðjungur hafði pessa skoðun um framhaldsskóla. Í ljós kom að hópurinn hafði allajafna litla menntun. Helmingur svarenda hafði eingöngu lokið grunnskólanámi. Priðjungur hafði byrjað í framhaldsskóla en hætt námi, oftast vegna veikinda, vanlíðunar eða námserfiðleika.

Eins og fram hefur komið getur brotthvarf úr námi aukið pörf fyrir félagslega aðstoð. Niðurstöður rannsóknar sem unnin var fyrir Velferðarsvið Reykjavíkurborgar á stöðu 1.300 barnafjölskyldna sem framfleyttu sér á fjárhagsaðstoð og atvinnuleysisbótum sýna að líkur á að einstaklingur sem piggur félagslega aðstoð hafi grunnskólapróf sem mestu menntun eru $61 \%$, en $31 \%$ að hann sé með menntun á framhaldsskólastigi og 9\% að hann sé með menntun á háskólastigi (Félagsvísindastofnun \& Rannsóknastofnun í barna og fjölskylduvernd 2012). Rannsökuð hefur verið staða og afdrif ungs fólks á aldrinum 18-24 ára sem fékk fjárhagsaðstoð í Reykjavík sex mánuði eða lengur á árunum 2008-2011 (Guðný Björk Eydal \& Klara Valgerður Brynjólfsdóttir 2015). Niðurstöður sýna að stór hluti unga fólksins bjó við fjölpættan vanda og slakan stuðning í nánasta umhverfi. Um var að ræða félagslega erfiðleika í uppeldi og ofbeldi í æsku og hafði Barnavernd haft afskipti af heimilum um fjórðungs pessara einstaklinga pegar peir voru börn. Um helmingur hópsins var óvinnufær vegna heilsubrests, margir áttu við geðræn vandkvæði að stríða og rúmlega 60\% áttu í vímuefnavanda. Mikill meirihluti hópsins, eða 85\%, hafði einungis lokið grunnskólanámi.

Hluti peirra sem hverfa frá námi í framhaldsskóla tekur upp práðinn aftur síðar á lífsleiðinni. Hér á landi hafa fleiri stundað framhaldsskólanám eftir 25 ára aldur en í nokkru öðru OECD-ríki (Jón Torfi Jónasson \& Andrea Gerður Dofradóttir 2009). Á síðustu áratugum hafa 15-20\% af hverjum árgangi lokið framhaldsskólaprófi talsvert löngu eftir hefðbundinn framhaldsskólaaldur (Gestur Guðmundsson \& Hulda Karen Ólafsdóttir 2013). Aðgangur fullorðinna að framhaldsskólum hér á landi hefur pó verið skertur verulega á undanförnum árum prátt fyrir að í gildi sé stefna um ævinám (Mennta- og menningarmálaráðuneytið 2015b). Skerðingin birtist fyrst í ákvæðum laga um framhaldsskóla nr. 92/2008 um forgangsröðun við innritun í framhaldsskóla fyrir 18 ára og yngri. Aðgengi eldri nemenda en 25 ára að framhaldsskólum var skert enn frekar árið 2015 (Pingskjal nr. 1/2014-2015). Með breytingu á reglugerð premur árum síðar (nr. 1150/2018) var pó horfið frá pessari ákvörðun.

Margir fullorðnir námsmenn hafa neikvæða reynslu af fyrri skólagöngu, og stafar 


\section{STJÓRNSÝSLA}

pað meðal annars af námserfiðleikum, geðrænum sjúkdómum, reynslu af einelti, erfiðum heimilisaðstæðum og ófullnægjandi stuðningi (Auður Sigurðardóttir 2010; Jónas Hörður Árnason 2015; Póra Ásgeirsdóttir 2009). Nýleg rannsókn á aðgengi fullorðinna að námi á framhaldsskólastigi bendir til að miklar og óparfar stofnanabundnar hindranir séu fyrir hendi í slakri upplýsingamiðlun, skipulagi námsins og staðsetningu pess (Elín Sif Welding Hákonardóttir, Sif Einarsdóttir, Arnheiður Gígja Guðmundsdóttir \& Gestur Guðmundsson 2017). Fram kom að pegar leiðin til náms var fundin urðu fjárhagslegar hindranir sýnilegri, einkum meðal peirra sem áttu börn. Einstaklingarnir upplifðu mikið álag við að sampætta vinnu og nám. Раð er á brattann að sækja fyrir stóran hluta ungs fólks að hefja nám að nýju, einkum pá sem eiga við námserfiðleika að etja. Рað er í andstöðu við siðferðilegan rétt ungs fólks að geta ekki stundað nám á peim forsendum sem pví hafa verið skapaðar (Guðmundur Heiðar Frímannsson 2006; Ólafur Páll Jónsson 2011).

\section{Umræða og ályktanir}

Hér hefur verið leitast við að gefa mynd af pekkingu á próun og stöðu skólans við að mæta flóknum pörfum barna og útvíkkuðu hlutverki kennarans í breyttu samfélagi. Spurningin sem leitað var svara við var pessi: Mætir umgjörð skólaumhverfisins pörfum nemenda og foreldra og breyttu hlutverki kennarans í nútímasamfélagi? Í stuttu máli sýnir pekking og umræða sérfræðinga að mikið skortir á að íslenskt skólakerfi geti mætt löggildri stefnu um skóla án aðgreiningar. Stjórnsýslulegri framkvæmd peirrar menntastefnu er ekki hagað í samræmi við rannsóknaniðurstöður og ályktanir fræðimanna á sviði mennta- og félagsvísinda. Í íslenskum stofnlögum er oft að finna ákvæði sem lýsa metnaðarfullum fyrirheitum. Đótt peim fyrirheitum sé allajafna pokað áfram með reglugerðum er peim ekki endilega fylgt eftir til samræmingar í öðrum lögum, í fjárlögum eða í framkvæmd.

Uppeldis- og velferðarhlutverk grunnskóla er skýrt í lögum og námskrám. Í pví felst að proska, móta og styrkja hæfileika nemenda og færni í samstarfi við foreldra, nemendum og samfélaginu til hagsbóta. Frá pví sjónarhorni ætti hlutverk skólans sem velferðarstofnunar að felast í beinum forvörnum með pví að huga að breyttum pörfum grunnskólanemenda, gæta siðferðilegs réttar peirra til tilvistarrýmis og sjá til pess að peir búi við öruggar aðstæður til proska og menntunar. Til pess parf náið samstarf fagfólks skólans við foreldra um sálfélagslega vellíðan barnsins, og stuðning við ábyrgðarhlutverk kennara, eins og Nanna Kristín Christiansen (2017) hefur rakið. Oft verða kennarar pess fyrstir áskynja, utan fjölskyldunnar, hvers er pörf í lífi barns. Đað er pó ekki á valdi kennara að ráða einir við pað ofurverkefni sem aðstoð við sum börn getur orðið. Đví er mikilvægt að samstarf sé haft við aðra sérfræðinga og að barnið geti notið víðtæks og samstillts stuðnings- og próunarstarfs. Рað er staðfest í rannsóknunum sem lýst er hér að framan.

Dótt vikið sé að hlutverki kennara í 12. gr. laga um grunnskóla (2008), og lýst skyldum peirra og ábyrgð, er par ekki að finna ákvæði um leiðir til að vernda og styrkja kennara, eða um útvíkkað hlutverk peirra við breyttar aðstæður. Samkvæmt sömu grein eiga peir 
„kost á reglulegri símenntun í peim tilgangi að efla starfshæfni sína“. Detta almenna ákvæði tryggir ekki skipulega (fag)handleiðslu í starfi til endurnýjunar og fagpróunar. Berja mætti í pann brest með sérlagaákvæðum.

Nýlega var haldin ráðstefna á vegum velferðarráđuneytisins (2018) um snemmtæka íhlutun í málefnum barna. Í ljósi niðurstaðna hér á undan er gagnlegt að tengja pessa umræðu við pað sem fram kom á ráðstefnunni. Samhljómur var um að skólinn purfi af fjölmörgum ástæðum að endurskoða áherslur sínar almennt og tryggja betur en áður hvernig komið er til móts við börn í skólastarfinu, einkum pau sem eiga í vanda. Hafa purfi í huga að heimurinn er að breytast, ef til vill miklu hraðar en íslenskir skólamenn gera sér grein fyrir (Ragnar Guðgeirsson, munnleg heimild 8. maí 2018). Fram kom áhersla á að samtal um skólastarfið purfi að eiga sér stað til að koma á sambandi milli fagfólksins innbyrðis og ekki síður milli stofnana og ráðuneyta heilbrigðis-, félags- og menntamála (Jón Torfi Jónasson, munnleg heimild 8. maí 2018). Pótt sambandsleysið sé víðast viðurkennt sé ekki nægilega á pví tekið. Samtalið sé til pess fallið að skapa traust milli faghópanna og aukinn skilning á mikilvægi samfellu og lipurðar í pverfaglegu samstarfi. Đetta verði peim mun mikilvægara eftir bví sem einstökum faghópum vex ásmegin 1 krafti eigin sérpekkingar. Pegar hætta skapast á gliðnun og jafnvel samkeppni milli faghópa um nýjar aðferðir, pá skipti máli að mynda samfléttaða liðsheild um sameiginlegt markmið. Árangri verði best náð innan skólans en jafnframt purfi að huga að samstarfi um lausnir utan hans. Hlutverk stjórnvalda sé hins vegar að styðja við breytingarnar og liðka fyrir peim, meðal annars pegar kemur að skilgreiningu á aðkomu ólíkra fagstétta innan skólans og forsendum snemmtækrar íhlutunar. Hægt sé að taka mið af breyttu umhverfi skólans, breyttri menningu og nýjum áherslum sem skólinn parf að hlutast til um á grunni laga. Pannig megi vinna að hugmyndinni um samtalið og pverfræðilega liðsheild sem geti stuðlað að pví að brjóta niður múra milli fagfólks og milli málaflokka. Slík skipan felur í sér vernd og forvarnaráhrif fyrir bæði kennara og unga nemendur. Kerfasamstarf getur ekki blómstrað í bútum eða eingöngu með pví að skiptast á pekkingu.

Efni pessar greinar er afmarkað við íslenskar aðstæður og hefur pví ekki verið vísað til einstakra erlendra rannsókna. Pegar á heildina er litið ber niðurstöðum peirra saman um að eigi skólinn sem menntastofnun að rísa undir nafni purfi umgjörð hans og skipan að stuðla að vellíðan allra nemenda á öllum skólastigum. Pá sé námsframvindu peirra fylgt eftir og pannig dregið úr brotthvarfi um leið og gætt er að framtíðarstöðu peirra á vinnumarkaði (Tomlinson 2012). Í samhljómi við petta eru áherslur íslenskra fræðimanna á vægi allra skólastiga, frá leikskóla til framhaldsskóla (Gerður G. Óskarsdóttir 2012). Detta varðar meðal annars umbætur í löggjöf um aðkomu aukins fagafls til afskipta pegar erfiðleikar og áföll verða í fjölskyldu skólabarns (sbr. kafla 3.1 og 3.4 hér að framan).

Af pví sem hér hefur verið dregið fram um afdrif brotthvarfsnemenda er ljóst að umtalsverður hluti peirra vill taka aftur upp práðinn með nýjum undirbúningi, endurhæfingu eða breyttu náms- og starfsvali í stað pess að vera ótímabært metnir öryrkjar og úr leik til samfélagspátttöku. Hér reynir á að stjórnvöld marki stefnu sem opnar pessum 
hópi fjölbreyttar leiðir. Um pær geti pessir nemendur síðan valið eftir persónulegum og námslegum forsendum sínum. Pannig má draga úr skaðsemi jaðarstöðu fyrir pá sem í henni lenda og skapa samfélaginu mannauð í stað vanvirkni og kostnaðar. Pessu má ná með markvissri náms- og starfsráðgjöf á framhaldsskólastigi, í tengslum við náms- og starfsmat endurhæfingarstofnana og í samstarfi við fagfólk velferðarpjónustu. Auk pess að koma í veg fyrir jaðarsetningu einstakra nemenda sem standa höllum fæti samræmist slík stefnumörkun hugmyndum um siðferðilegan rétt allra til náms og siðrænum gildum um að virkja beri hvern og einn á sínum forsendum til starfs og samfélagspátttöku. Рað felur einnig í sér beinan pjóðhagslegan ávinning.

Niðurstaða pessarar greinar er sú að lausn á vanda kennara og skólabarns felist ekki í að skipuleggja starfsemi í kringum námsvanda eða láta staðar numið við greiningu eða „vandamálastimpil“. Heildstæð pverfagleg starfsemi er til pess fallin að komast fyrir vandann og fylgifiska hans.

Að lokum skal hnykkt á nokkrum atriðum sem álykta má um út frá peirri heildarmynd sem lýst er í greininni. Nauðsynlegt er í fyrsta lagi að bæta í lög ákvæðum sem stuðla að pví að tryggja pverfaglegt teymisstarf á öllum skólastigum sem bakhjarl hins útvíkkaða hlutverks kennarans. Slíkt starf er háð ráðningu sérfræðinga, skólahjúkrunarfræðinga, skólafélagsráðgjafa, náms- og starfsráðgjafa og annarra sem hafa heildarsýn á kerfasamstarf ásamt pekkingu á löggjöf, farvegum og pjónustuúrræðum velferðarsamfélagsins. Í öðru lagi parf sérfræðiteymi að virkja verkferla áfallateyma pegar við á pannig að pau gagnist hinu einstaka skólabarni og fjölskyldu pess. Í priðja lagi er pörf á lagaákvæðum um heildrænt kerfasamstarf skóla, heilsugæslu og félagspjónustu, sem um leið stuðli að fjölfaglegu samstarfi innan skóla og utan. Í pví felst að í hverjum sérlögum sé vísað til lagaákvæða á öðrum sviðum sem taka til sjálfstæðs réttar barna til upplýsinga, pátttöku og verndar.

Í samræmi við niðurstöður rannsókna um nauðsyn pessara umbóta hafa nú á vordögum 2019 verið sampykkt á Alpingi lagaákvæði um aukinn rétt barna sem aðstandenda og um sjálfstæðan rétt peirra til pátttöku, upplýsinga og stuðnings í heilbrigðispjónustu og í skóla samkvæmt verklagsreglum (Pingskjal nr. 273/2018-2019). Með tilkomu pessara lagabóta er stigið mikilvægt skref til að skilgreina skyldur velferðarpjónustu og aðkomu skólans að rétti og pörfum skólabarna. Með pessu er einnig stutt við hlutverk kennarans í breyttum samfélagsaðstæðum.

\section{Lokaorð}

Meginniðurstaða pessarar greinar er að misræmi sé á milli opinberrar menntastefnu um að mæta pörfum allra nemenda og stjórnsýslulegrar framkvæmdar hennar, sem fela á í sér stuðning við börn, foreldra og kennara. Færð eru rök fyrir pví að aukinn styrkur í fagpjónustu innan skóla og samræmt samstarf við opinbera velferðarpjónustu opni leið til að brúa bil milli opinberrar stefnu og lagaákvæða annars vegar og hins vegar starfsaðstæona skólans í reynd. Pær breytingar til bóta sem hér er bent á parfnast frekari rannsókna, viðhorfsbreytinga og próunar úrlausna á grunni pekkingar og laga. 


\section{Aftanmálsgrein}

1 Frumvarpið varð að lögum 4. júní 2019

\section{Heimildir}

Allen, M. og Ashbaker, B.Y. (2004). „Strengthening schools: Involving paraprofessionals in crisis prevention and intervention", Intervention in School and Clinic 39(3), 139-146. Sótt af http://journals. sagepub.com/doi/pdf/10.1177/10534512040390030201

Auður Sigurðardóttir (2010). Að stíga skerefið: Í nám á nýjan leik að loknu raunfarnimati (Óbirt MA rigerð). Háskóli Íslands, Reykjavík. Sótt af http://hdl.handle.net/1946/4382

Birna Sigurjónsdóttir (2017). „Viðauki 3: Skýrsla um starfsaðstæður kennara - Niðurstöður úr rýnihópum kennara í grunnskólum Reykjavíkur um bókun 1 í kjarasamningi“, í Nýlidun og batt starfsumbverfi grunnskólakennara (bls. 45-67). Sótt af https://reykjavik.is/sites/default/files/sfs_starfsumhverfi_grunnskolakennara-skyrsla_starfshops_um_nylidun_og_baett_starfsumhverfi_grunnskolakennara_i_reykjavik_2017-lok121217.pdf

Björk Vilhelmsdóttir (2018). „Horfur ungs fólks sem er hvorki í námi né vinnu. Ársrit um starfsendurhæfingu“, Ársrit um starfsendurhæfingu [útg. VIRK], 34-35. Sótt af http://www.virk.is/static/ files/_2016/fjolmidlar/virk_2018_arsrit-net.pdf

Corin, C. og Björk, L. (2016). „Job demands and job resources in human service managerial work: An external assessment through work content analysis“, Nordic Journal of Working Life Studies 6(4), 3-28. https://doi.org/10.19154/njwls.v6i4.5610

Dyregrov, A. (1993). Beredskapsplan för skolan, barn i sorg. Stokkhólmur: Rädda Barnen.

Eiríkur Sigurðsson (2014). Bjóðfélagslegur kostnaður af brotthvarfi úr námi á framhaldsskólastigi. Reykjavík: Samtök sveitarfélaga á höfuðborgarsvæðinu. Sótt af https://ssh.is/images/stories/ S\%C3\%B3knar\%C3\%A1\%C3\%A6tlun/Lokaskyrslur/Sk\%C3\%B3lar/Brotthvarf_ur_framhaldssk_ENDANLEG.pdf

Elfa María Geirsdóttir (2016). Viðbrögð leik- og grunnskóla við andláti i fjölskyldu skólabarns (Óbirt MA ritgerð). Háskóli Íslands, Reykjavík. Sótt af http://hdl.handle.net/1946/26413

Elín Sif Welding Hákonardóttir, Sif Einarsdóttir, Arnheiður Gígja Guðmundsdóttir og Gestur Guðmundsson (2017). „Aðgengi fullorðinna að námi á framhaldsskólastigi: Stofnana- og aðstæðubundnar hindranir á menntavegi“, Tímarit um uppeldi og menntun 26(1-2), 65-86.

Ella Kristín Karlsdóttir, Guðrún H. Sederholm, Sigrún Júlíusdóttir og Valgerður Halldórsdóttir (2005). Félagsrádgöö - bluti af faglegri pjónustu á öllum skólastigum: Greinargerò um próun skólafélagsrádgjafar á Íslandi. Óbirt skýrsla.

Félagsvísindastofnun Háskóla Íslands (2016). Stada ungs fólks með örorku- eða endurbafingarlifeyri. Sótt af http://www.velferdarraduneyti.is/media/skyrslur2016/Stada_ungs_folks_med_ororku_13.10.2016. pdf

Félagsvísindastofnun Háskóla Íslands og Rannsóknastofnun í barna- og fjölskylduvernd (2012). Aðstaður reykviskkra foreldra: Félagslegt tengslanet, tómstundir og almennt heilsufar barna. Sótt af https:// reykjavik. is/sites/default/files/ymis_skjol/skjol_utgefid_efni/adstaedur_reykviskra_foreldra_030512.pdf

Franklin, C., Harris, M.B. og Montgomery, K.L. (2015). „The delivery of school social work services“, í P. Allen-Meares (ritstj.), Social Work Services in Schools (bls. 124-158). Chicago: University of Illinois (frumútg. 1985).

Fræðslumiðstöð Reykjavíkur (2000). Sérkennsla í grunnskólum Reykjavíkur: Könnun á fjölda nemenda, ástaðum og framkvamd. Sótt af https://reykjavik.is/sites/default/files/skjol_thjonustulysingar/serkennsla_i_ grunnskolum.pdf

Gerður G. Óskarsdóttir (1995). The forgotten half. Comparison of dropouts and graduates in their early work experience: The Icelandic case. Reykjavík: Félagsvísindastofnun Háskóla Íslands og Háskólaútgáfan.

Gerður G. Óskarsdóttir (2012). Skil skólastiga: Frá leikskóla til grunnskóla og grunnskóla til frambaldsskóla. Reykjavík: Háskólaútgáfan. 


\section{STJÓRNSÝSLA}

Gestur Guðmundsson (2002). Breytt umskipti til fullordinsaldurs: Áfangaskýrsla október 2002. Sótt af http://reykjavik.is/sites/default/files/ymis_skjol/skjol_utgefid_efni/gestur_gudmundsson_umskipti11102.pdf

Gestur Guðmundsson og Hulda Karen Ólafsdóttir (2013). „Brotthvarf og endurkoma fullorðinna í nám á framhaldsskólastigi“, Tímarit um menntarannsóknir 10(1), 44-64.

Gretar L. Marinósson (1998). „Hvernig á skólinn að vera?“, Ný menntamál 16(1), 24-28.

Gretar L. Marinósson og Kristín P. Magnúsdóttir (2016). „Greiningarheiti grunnskólanema“, í Dóra S. Bjarnason, Hermína Gunnpórsdóttir og Ólafur Páll Jónsson (ritsti.), Skóli margbreytileikans (bls. 137-155). Reykjavík: Háskólaútgáfan og Rannsóknarstofa um skóla án aðgreiningar.

Guðbjörg Ólafsdóttir og Berglind Rós Magnúsdóttir (2017). „Milli steins og sleggju: Hugmyndir umsjónarkennara um faglegt sjálfstæði sitt til að tryggja fulla pátttöku allra nemenda í efstu bekkjum grunnskóla“, Netla - Veftimarit um uppeldi og menntun: Sérrit 2017 - Menntakvika 2017. Sótt af http:// netla.hi.is/serrit/2017/menntakvika_2017/005.pdf

Guðmundur Heiðar Frímannsson (2006). „Introduction: Is there a Nordic model in education?“, Scandinavian Journal of Educational Research 50(3), 223-228.

Guðný Björk Eydal og Klara Valgerður Brynjólfsdóttir (2015). „Ungt fólk í kreppu: Atvinnu-, fjárhagsog félagsstaða“, Tímarit félagsráðgjafa 9(1), 19-24.

Guðríður Adda Ragnarsdóttir (1998). „Бjónusta sérfræðinga við börn í grunnskólum“, Ný menntamál 16(1), 29-35.

Guðrún Kristinsdóttir (2011). Barnavernd: Kennsluefni. Reykjavík: Höfundur.

Gunnar E. Finnbogason (1998). Affoll i nemendabópnum: Sorgin hefur mörg andlit: Handbók um áföll i skólum. Reykjavík: Höfundur.

Gunnar E. Finnbogason og Hildur Björg Gunnarsdóttir (2010). „Tilvist og uppbygging áfallaáætlana í grunnskóla“, Rádstefnurit Netlu - Menntakvika 2010. Menntavísindasvið Háskóla Íslands. Sótt af http://netla.hi.is/menntakvika2010/alm/012.pdf

Hagstofa Íslands (2016.) „Rúmur fjórðungur grunnskólanemenda fær stuðning“. Sótt af http://hagstofa.is/utgafur/frettasafn/menntun/skolahald-i-grunnskolum-2014-2015/

Hermína Gunnpórsdóttir og Dóra S. Bjarnason (2014). „Conflicts in teachers’ professional practices and perspectives about inclusion in Icelandic compulsory schools", European Journal of Special Needs Education 29(4), 491-504. http://dx.doi.org/10.1080/08856257.2014.933543

Hjern, A., Berg, L., Rostila, M. og Vinnerljung, B. (2013). Barn som anböriga: Hur går det i skolan? [Önnur skýrsla úr verkefninu „Barn som anhöriga“]. Stokkhólmi: Nationellt kompetenscentrum.

Ingibjörg H. Jónsdóttir (2017). „Vinnutengd streita. Orsakir, úrræði og ranghugmyndir“", Ársrit um starfsendurhæfingu [útg. VIRK], 55-57. Sótt af https://www.virk.is/static/files/virk-a-rsrit_2017_net.pdf

Ingólfur Ásgeir Jóhannesson (2006a). ,'Different children - a tougher job’. Icelandic teachers reflect on changes in their work“, European Educational Research Journal 5(2), 140-151. https://doi.org/10.2304/ eerj.2006.5.2.140

Ingólfur Ásgeir Jóhannesson (2006b). „"Strong, independent, able to learn more ...”: Inclusion and the construction of school students in Iceland as diagnosable subjects", Discourse 27, 103-119.

Ingvar Sigurgeirsson og Ingibjörg Kaldalóns (2006). „Gullkista við enda regnbogans": Rannsókn á hegounarvanda i grunnskólum Reykjavíkur skólaárid 2005-2006. Reykjavík: Rannsóknarstofnun Kennaraháskóla Íslands.

Jóhanna Rósa Arnardóttir (2015). „Leið ungmenna frá skóla til vinnu“, Tímarit félagsráogjafa 9(1), 46-51.

Jón Torfi Jónasson (2008). „Skóli fyrir alla?“, í Loftur Guttormsson (ritstj.), Almenningsfraosla á Íslandi 1880-2007: Skóli fyrir alla 1946-2007 (bls. 272-291). Reykjavík: Háskólaútgáfan.

Jón Torfi Jónasson og Andrea Gerður Dofradóttir (2009). Dátttaka í fræðslu á Íslandi: Niðurstöður úr vinnumarkaðsrannsókn Hagstofunnar 2003. Reykjavík: Rannsóknarstofa um menntakerfi og Félagsvísindastofnun HÍ.

Jón Torfi Jónasson og Guðbjörg Andrea Jónsdóttir (1992). Námsferill i frambaldsskóla. Reykjavík: Félagsvísindastofnun Háskóla Îslands. 
Jón Torfi Jónasson og Kristjana Stella Blöndal (2002). Ungt fólk og frambaldsskólinn: Rannsókn á námsgengi og afstödu '75 árgangsins til náms. Reykjavík: Félagsvísindastofnun Háskóla Íslands og Háskólaútgáfan.

Jónas Hörður Árnason (2015). Brottfallsnemar á námsstyrk (Óbirt MA ritgerð). Háskóli Îslands, Reykjvík. Sótt af http://hdl.handle.net/1946/21131

Kristjana Stella Blöndal og Atli Hafpórsson (2018). „Margbreytileiki brotthvarfsnemenda“, Netla - veftímarit um uppeldi og menntun. Sérrit 2018 - Frambaldsskólinn i brennidepli. Sótt af http://netla.hi.is/ serrit/2018/framhaldskolinn_brennidepli/11.pdf

Lög um framhaldsskóla nr. 92/2008.

Lög um fræðslu barna nr. 59/1907.

Lög um grunnskóla nr. 63/1974.

Lög um grunnskóla nr. 49/1991.

Lög um grunnskóla nr. 66/1995.

Lög um grunnskóla nr. 91/2008.

Lög um vernd barna og ungmenna nr. 53/1966.

Menntamálaráðuneytið (1995). Salamanca-yfirlýsingin og rammaáatlun um adgerdir vegna nemenda með sérparfir. Reykjavík: Höfundur.

Menntamálaráđuneytið (1998). Efling náms- og starfsrádgjafar: Nefndarálit. Sótt af https://fns.is/sites/default/files/stjorn/Efling_nams\&starfsradgjafar2.pdf

Menntamálaráđuneytið (1999). Aðalnámskerá grunnskóla. Almennur bluti. Reykjavík: Höfundur.

Mennta- og menningarmálaráðuneytið (2015a). Mat á framkvamd stefnu um skóla án adgreiningar: Skýrsla starfshóps. Reykjavík: Höfundur.

Mennta- og menningarmálaráðuneytið (2015b). Skýrsla verkefnabóps um fullorðins- og framhaldsfreðslu. Reykjavík: Höfundur.

Mennta- og menningarmálaráðuneytið (2017). „Menntun fyrir alla á Íslandi: Úttekt á framkvæmd stefnu um menntun án aðgreiningar“. Sótt af http://www.stjornarradid.is/efst-a-baugi/frettir/stokfrett/2017/03/02/Uttekt-a-framkvaemd-stefnu-um-menntun-an-adgreiningar/

Menntasvið Reykjavíkurborgar (2008). Skýrsla starfshóps um sérfraðïjónustu skóla. Reykjavík: Höfundur.

Nanna Kristín Christiansen (2011). Skóli og skólaforeldrar: Ný sýn á samstarfio um nemandann. Reykjavík: Iðnú.

Nefnd samkvæmt lögum nr. 26/2007 (2008). Könnun á starfsemi Breidavíkurbeimilisins 1952-1979 [skýrsla sem forsætisráðherra lagði fyrir 135. löggjafarping 2007-2008]. Reykjavík.

Nefnd um sérkennslu og sérúrræði í Reykjavík (2002). Stefna fraðsluráds Reykjavíkur um sérkennslu. Sótt af https://reykjavik.is/sites/default/files/ymis_skjol/skjol_utgefid_efni/stefna_um_serkennslu.pdf

Norræna rádherranefndin (2018). State of the Nordic Region 2018. http://dx.doi.org/10.6027/ NORD2018-001

OECD (2018). Youth not in employment, education or training (NEET). doi: 10.1787/72d1033a-en

Ólafur Páll Jónsson (2011). Lyjđraði, réttlati og menntun: Hugleidingar um skilyroji mennskunnar. Reykjavík: Háskólaútgáfan.

Ragnar F. Ólafsson og Kristín Jónsdóttir (2006). „Á hverju byggir pú petta? Hvar eru gögnin? Viðtal við Gerði G. Óskarsdóttur um nýtingu rannsóknarniðurstaðna í stefnumótun og próunarstarfi“", Tímarit um menntarannsóknir 3(1), 82-95.

Reglugerð um breytingu á reglugerð um innritun nemenda í framhaldsskóla nr. 1150/2018.

Reglugerð um ráðgjafar- og sérfræðipjónustu grunnskóla nr. 21/1980.

Reglugerð um sérkennslu nr. 270/1977.

Samband íslenskra sveitarfélaga (2015). „Rúmlega 25\% nemenda njóta stuðnings“, Tídindi 1(3). Sótt af http://www.samband.is/tidindi/2015/1.-tbl.-2015/studningur/

Samband íslenskra sveitarfélaga (2017). „Lykiltölur úr rekstri sveitarfélaga 2017““. Sótt af https://www. samband.is/media/tolfraedilegar-upplysingar/Upplysingarit_10_2018.pdf

Samband íslenskra sveitarfélaga og Félag grunnskólakennara (2012). „Sameiginleg könnun Sambands ís- 


\section{STJÓRNSÝSLA}

lenskra sveitarfélaga og Félags grunnskólakennara“. Sótt af http://ssh.is/images/stories/Soknaraaetlun/Kynning_nidurstadna_konnunar_FG_og_samb_loka_2012_08.pdf

Sigrún Harðardóttir (2015a). Lỉ̇an frambaldsskólanemenda: Um námserfiðleika, ábrifapatti og ábyrgð samfélags. Reykjavík: Rannsóknastofnun í barna og fjölskylduvernd.

Sigrún Harðardóttir (2015b). „Velferð nemenda - hlutverk skólafélagsráðgjafa“, Tímarit félagsrádgjafa $9(1), 7-12$.

Sigrún Harðardóttir og Ingibjörg Karlsdóttir (bíður birtingar). „Hlutverk kennara og velferð barna í skóla án aðgreiningar“.

Sigrún Júlíusdóttir (1998). „Menntastefna og mannvernd: Um manngildi og faglegt samstarf í skólum“, Ný menntamál 16(2), 34-39.

Sigrún Júlíusdóttir (2001). Fjölskyldur við aldahvörf. Reykjavík: Háskólaútgáfan.

Sigrún Júlíusdóttir (2005). „Fjölskyldur í ölduróti - umgjörð og innviðir“", í Ungir Íslendingar í ljósi vísindanna (bls. 255-262). Reykjavík: Háskólaútgáfan.

Sigrún Júlíusdóttir (2012). „Fjölskyldur - umbreytingar, samskipti og skilnaðarmál“, í Guðný Björk Eydal og Stefán Ólafsson (ritstj.), Próun velferðarinnar 1988-2008 (bls. 69-89). Reykjavík: Félagsvísindastofnun.

Sigrún Júlíusdóttir og Gunnjóna Una Guðmundsdóttir (2017). „Foreldri fær krabbamein - viðkvæm staða barna“, í Sigrún Júlíusdóttir (ritsti.), Ritröo um rannsóknaverkefni á svið̇ félagsrádgjafar 10. hefti. Reykjavík: Rannsóknastofnun í barna- og fjölskylduvernd.

Sigrún Júlíusdóttir, Gunnjóna Una Guðmundsdóttir og Edda Jóhannsdóttir (2015). „Рað skiptir bara öllu máli hvernig við undirbúum börnin.“: Greinargerð um rýnihópasamræðu fagfólks: Fyrsti hluti rannsóknar um stöðu barna við andlát foreldris“, í Sigrún Júlíusdóttir (ritstj.), Ritröð um rannsóknaverkefni á svidi félagsrádgjafar 9. hefti. Reykjavík: Rannsóknastofnun í barna- og fjölskylduvernd.

Sigrún Júlíusdóttir, Gunnjóna Una Guðmundsóttir og Sigurlína Davíðsdóttir (2018). „Gæðapjónusta fyrir barnafjölskyldur með krabbamein“, í Sigrún Júlíusdóttir (ritstj.), Ritröơ um rannsóknarverkefni á svidi félagsrádgjafar 11. hefti. Reykjavík: Rannsóknastofnun í barna- og fjölskylduvernd.

Sigrún Júlíusdóttir og Sólveig Sigurðardóttir (2013). Eftir skilnad: Um foreldrasamstarf og kynslódatengsl. Reykjavík: Háskólaútgáfan og Rannsóknastofnun í barna- og fjölskylduvernd.

Skóla- og frístundaráo Reykjavíkurborgar (2017). Nýliðun og bætt starfsumhverfi grunnskólakennara [skýrsla starfshóps um nýliðun og bætt starfsumhverfi grunnskólakennara]. Reykjavík: Höfundur.

Snæfríður Dröfn Björgvinsdóttir og Anna-Lind Pétursdóttir (2014). „Erfið hegðun nemenda: Áhrif á líðan kennara“, Uppeldi og menntun 23(2), 65-86.

Stefán Ólafsson og Arnaldur Sölvi Kristjánsson (2017). Ójöfnudur á Íslandi: Skipting tekna og eigna i fjölpjódlegu sambengi. Reykjavík: Háskólaútgáfan.

Stefán Ólafsson og Jóhanna Rósa Arnardóttir (2008). „From school to work: The case of Iceland“, í J. Olofsson og A. Panican (ritsti.), Ungdomars väg frän skola till arbetslivet: Nordiska erfarenheter (bls. 191-245). Kaupmannahöfn: Norræna ráðherraráðið.

Tomlinson, S. (2012). „The irrestible rise of the SEN industry“, Oxford Review of Education 38(3), 267 286. http://dx.doi.org/10.1080/03054985.2012.692055

Trausti borsteinsson og Amalía Björnsdóttir (2016). „Stjórnun og fagleg forysta í grunnskólum“, Stjórnmál \& stjórnsýsla 12(2), 487-510.

Velferðarráðuneytið (2018). „SIMBI“ [Dagskrá og upptökur frá Ráðstefnu um snemmtæka íhlutun í málefnum barna, 8. maí 2018.]. Sótt af https://www.stjornarradid.is/verkefni/felags-og-fjolskyldu$\mathrm{mal} / \mathrm{malefni}$-barna/simbi/

Velferðarvaktin (2017). „Tillögur Velferðarvaktarinnar um aðgerðir til að auka hlutfall nemenda sem ljúka framhaldsskólanámi“, 29. nóvember. Sótt af https://www.stjornarradid.is/verkefni/allarfrettir/frett/2017/11/30/Tillogur-Velferdarvaktarinnar-gegn-brotthvarfi-nemenda-ur-framhaldsskolum/

Vigdís Jónsdóttir (2017). „Að auka vinnugetu og pátttöku á vinnumarkaði: Staðan, orsakir, kerfislægar 
hindranir og tillögur til úrbóta“, Ársrit um starfsendurhæfingu [útg. VIRK], 6-19. Sótt af http:// www.virk.is/static/files/virk-a-rsrit_2017_net.pdf

Vinnumálastofnun (2019). „Vinnumarkaðurinn á Íslandi. Yfirlit, horfur og pjónusta Vinnumálastofnunar - Apríl 2019“. Sótt af https://www.vinnumalastofnun.is/media/2244/april-2019-skyrsla-lok.pdf

pingskjal nr. 1/2014-2015. „Frumvarp til fjárlaga fyrir árið 2015“. Sótt af https://www.althingi.is/ altext/144/s/pdf/0001.pdf

bingskjal nr. 273/2018-2019. „Frumvarp til laga um breytingu á ýmsum lögum vegna réttar barna sem aðstandenda“ [flm. Vilhjálmur Árnason, Andrés Ingi Jónsson, Ólafur Îsleifsson, Guðjón S. Brjánsson, Helga Vala Helgadóttir, Anna Kolbrún Árnadóttir]. Sótt af https://www.althingi.is/altext/ pdf/148/s/1269.pdf ${ }^{1}$

Dorsteinn Sigurðsson. (1993). Dættir úr sögu sérkennslunnar. Reykjavík: Pórsútgáfan.

Póra Ásgeirsdóttir. (2009). „Ég var bara tossi“: Niðurstöður könnunar sem lögð var fyrir pátttakendur 1 les- og skrifblindunámi á vegum símenntunarmiðstöðva“, Gátt - Ársrit um fullorơinsfrà̀slu og starfsmenntun, 64-67. Sótt af http://frae.is/wp-content/uploads/2018/07/Gátt-2009_web_064-067.pdf

pórunn Sveinbjarnardóttir. (2018). „Álag, streita, kulnun og kyn“, Ársrit um starfsendurhæfingu [útg. Virk], 4-5. Sótt af http://www.virk.is/static/files/_2016/fjolmidlar/virk_2018_arsrit-net.pdf 